\title{
Application of Experimental Design by Differential Pulse Voltammetry for Determination of Rare Elements as Complexes with Diethylenetriaminepentaacetic Acid (DTPA)
}

\author{
Santhy Wyantuti, Uji Pratomo, Yeni Wahyuni Hartati, Diana Hendrati, Husein H. Bahti
}

\begin{abstract}
Rare earth elements have been known as the importance material in modern technology. Since the presence of these materials in environment is very small concentration, the development method for fast and sensitive detection is challenging. Instead of relatively expensive ICP-MS instrument, the utilization of voltammetry method to answer the task of fast and sensitive detection is considerably cheaper. In the present work, a complex of Gadolinium (Gd) and Terbium (Tb) with diethylentriaminepentaacetic acid (DTPA) ligand was studied by experimental design to obtain the optimum condition detection of differential pulse voltammetry. The Plackett-Burman design was selected as the method. The positive response was optimized based on Box-Behnken. Optimum experimental condition was achieved by using scan rate of $0.05 \mathrm{Vs}^{-1}$, amplitude pulse of $0.5489 \mathrm{~V}$, ligand concentration of $267.67 \mathrm{mgL}^{-1}, \mathrm{pH}$ of 5.15 and the electrolyte solution of ammonium chloride of $0.1 \mathrm{M}$. Under the optimum experimental condition, the precision and accuracy were found as $99.7 \%$ and $97.4 \%$ for Gd-DTPA; and $99.5 \%$ and $91.4 \%$ for Tb-DTPA. The detection limit and quantization limit values for Gd-DTPA were $27.11 \mathrm{mgL}^{-1}$ and $92.33 \mathrm{mgL}^{-1}$, respectively; and Tb-DTPA were $27.69 \mathrm{mgL}^{-1}$ and $92.34 \mathrm{mgL}^{-1}$, respectively.
\end{abstract}

Index Terms: Box-Behnken, Diethylenetriaminepentaacetic Acid, Plackett-Burman, Voltammetry, Rare-Earth Elements.

\section{INTRODUCTION}

Gadolinium (Gd) and Terbium ( $\mathrm{Tb}$ ) are ubiquitous for production of modern materials. Gadolinium is used as a material for a magnet, X-ray screen, high-temperature electrolyte, and contrast agent Magnetic Resonance Imaging, while Terbium is used as a material for preparing fluorescence lamp [1]. The present of $\mathrm{Gd}$ and $\mathrm{Tb}$ in the

Revised Manuscript Received on April 25, 2019.

Santhy Wyantuti, Department of Chemistry, Faculty of Mathematics and Science, University of Padjadjaran, Jalan Raya Bandung Sumedang KM. 21, West Java, Indonesia.

Uji Pratomo, Department of Chemistry, Faculty of Mathematics and Science, University of Padjadjaran, Jalan Raya Bandung Sumedang KM. 21, West Java, Indonesia.

Yeni Wahyuni Hartati, Department of Chemistry, Faculty of Mathematics and Science, University of Padjadjaran, Jalan Raya Bandung Sumedang KM. 21, West Java, Indonesia.

Diana Hendrati, Department of Chemistry, Faculty of Mathematics and Science, University of Padjadjaran, Jalan Raya Bandung Sumedang KM. 21, West Java, Indonesia.

Husein H. Bahti, Department of Chemistry, Faculty of Mathematics and Science, University of Padjadjaran, Jalan Raya Bandung Sumedang KM. 21, West Java, Indonesia. environment are rare and have unique chemical properties such as the same valence and close ion radius [2]-[4], which is attractive to scientists to invent a method for fast detection in small concentrations.

One of the best methods for rare earth element analysis is using ICP-MS. This method is very simple, sensitive and requires small amount of sample. However, there are still spectral disturbances that are lacking in this method ${ }^{5}$. Therefore, it is interesting to prepare some method as a replied to this challenge. The voltammetric method offering simple sample preparation, fast analysis time, low detection limits, and good reproducibility. Simple sample preparation without separation from major elements is an advantage to reduce the source of error with a detection limit of up to $0.1 \mu \mathrm{g}$ / L [5]-[7]. Moreover, voltammetry method provides high sensitivity, wide linear range, accurate, precise and cost-effective [8]. A combination of this method with multivariate analysis can be mutual for preparing a fast and simultaneous analysis method. By this combination, a small number of responses of the entire voltammetric profile can be transformed to the equation model to predict the optimal condition [9]-[12].

Diethylenetaminepentaacetic acid (DTPA) is a famous octadentate ligand which can bind metal ions through five protonated carboxylic groups and three tertiary amino groups. DTPA has five acetic linked by a molecular backbone which formed stable complexes like EDTA. This ligand was used in a variety of industrial applications [13].

In this research, a differential pulse voltammetry method will be developed using pencil graphite electrode to obtain the response of $\mathrm{Gd}$ and $\mathrm{Tb}$ as complexes with DTPA. The optimum conditions of analysis were determined by experimental design to shorten the experimental time and reduce the chemicals used. We believed this result is beneficial to join the race of green analysis by reducing the solvent and time consumption.

\section{MATERIALS AND METHODS}

\section{A. Materials}

The instruments that were used in this research are various glass tools, reference electrode was $\mathrm{Ag} / \mathrm{AgCl}$

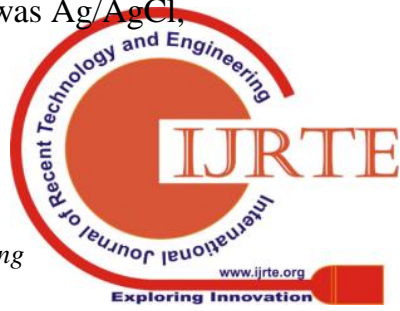




\section{Application of Experimental Design by Differential Pulse Voltammetry for Determination of Rare Elements as Complexes with Diethylenetriaminepentaacetic Acid (DTPA)}

the working electrode was graphite pencil Faber-Castell HB $0.5 \mathrm{~mm}$, auxiliary electrode was platinum wire, all electrochemical measurements were carried out in a $10 \mathrm{~mL}$ voltammetric cell, micro pipette (Eppendorf), potentiostat was Metrohm ${ }^{\circledR} \mu$ Autolab connected to computer using software NOVA 7.0.0, $\mathrm{pH}$ meter was Jenway 3505 and Design Expert DX 10.0.1.0 software.

\section{B. Reagents}

A Stock solution of gadolinium and terbium with concentration $1000 \mathrm{mg} \mathrm{L}^{-1}$ respectively were prepared by dissolving gadolinium oxide and terbium oxide (Aldrich, 99.9\%) with concentrated nitric acid and diluted with Mili-Q, ammonium chloride (Merck), DTPA (Aldrich), sodium hydroxide and hydrochloric acid.

\section{Electrochemical detection of Gd-DTPA and Tb-DTPA by differential pulse voltammetry}

Graphite pencil, $\mathrm{Ag} / \mathrm{AgCl}$ and platinum wire electrodes were immersed into an electrochemical cell, which contained $3 \mathrm{~mL}$ of DTPA solution, $3 \mathrm{~mL}$ of standard $\mathrm{Gd}$ or Tb solution and $4 \mathrm{~mL}$ of the electrolyte solution. The $\mathrm{pH}$ condition of the solution in the electrochemical cell was adjusted using $\mathrm{pH}$ meters. The three electrodes are connected to the potentiometer. The measurements were done by using differential pulse voltammetry with potential ranges of -1.25 to $1.25 \mathrm{~V}$, deposition time was $60 \mathrm{~s}$, scanning rate and amplitude pulse was adjusted following the optimum conditions of the experimental design.

\section{RESULT AND DISCUSSION}

\section{A. Optimum Condition using the Plackett-Burman and Box Behnken experimental design}

The Plackett-Burman experimental design is a first-order design that used to determine the selected factors that affect the response. In this study, the selection of factors that affected to the differential pulsed voltammetric analysis of $\mathrm{Gd}$ and $\mathrm{Tb}$ was determined. The Design Expert DX 10.0.1.0 was used to select the potential factor. The factors that have potential effect on the voltammetric analysis are listed in table 1.

Table 1. The factor that has potential effect on the voltammetric analysis

\begin{tabular}{|l|c|c|}
\hline Factors & $\begin{array}{c}\text { Highest } \\
(+1)\end{array}$ & Lowest (-1) \\
\hline $\mathrm{X}_{1}$. Potential deposition & $-1.0 \mathrm{~V}$ & $-1.5 \mathrm{~V}$ \\
\hline $\mathrm{X}_{2}$. Time deposition & $80 \mathrm{~s}$ & $40 \mathrm{~s}$ \\
\hline $\mathrm{X}_{3}$. Pretreatment & Yes & No \\
\hline $\mathrm{X}_{4}$. Stirring & Yes & No \\
\hline $\mathrm{X}_{5}$. Supporting electrolyte solution & $\mathrm{NH}_{4} \mathrm{Cl}$ & $\mathrm{H}_{2} \mathrm{O}$ \\
\hline $\mathrm{X}_{6}$. Potential range & $\begin{array}{c}-1.5 \text { to } \\
+1.5 \mathrm{~V}\end{array}$ & $\begin{array}{c}-1.0 \text { to } \\
+1.0 \mathrm{~V}\end{array}$ \\
\hline $\mathrm{X}_{7}$. Scan rate & $0.05 \mathrm{~V} / \mathrm{s}$ & $0.01 \mathrm{~V} / \mathrm{s}$ \\
\hline $\mathrm{X}_{8}$. Ligand concentration & $\begin{array}{c}392.41 \\
\mathrm{mgL}^{-1}\end{array}$ & $\begin{array}{c}261.61 \\
\mathrm{mLL}^{-1}\end{array}$ \\
\hline $\mathrm{X}_{9}$. pH & 7 & 5 \\
\hline $\mathrm{X}_{10}$. Amplitudes pulse & $0.1 \mathrm{~V}$ & $0.05 \mathrm{~V}$ \\
\hline $\mathrm{X}_{11}$. Dummy & - & - \\
\hline
\end{tabular}

As shown in table 1, the factors that has effect for voltammetry analysis for Gd and Tb with DTPA are potential deposition, deposition time, pretreatment, stirring, electrolyte solution, potential range, ligand concentration, scan rate, $\mathrm{pH}$, amplitude pulse and dummy.

Further, a Plackett-Burman design method was used to assign the 12 experimental run plans for 11 potential factors as shown in table 2 .

We obtained the Plackett-Burman coefficient of response function by using multiple linear equations (Equation 1) from 11 factors as:

$$
\begin{aligned}
& Y=3.2 \times 10^{-3}-7 \times 10^{-4} X_{1}-3.18 \times 10^{-5} X_{2}-4.02 \times 10^{-6} X_{3}-1.1 \times 10^{-3 X_{4}}+ \\
& 9 \times 10^{-4} X_{5}-2 \times 10^{-4} X_{6}+6 \times 10^{-4} X_{7}+6 \times 10^{-4} X_{8}+8 \times 10^{-4} X_{9}+ \\
& 4 \times 10^{-4} X_{10}+3 \times 10^{-4} X_{11}
\end{aligned}
$$

From equation (1), we can determine the selected factors which have a positive influence or significantly affect the response which are the supporting electrolyte solution $\left(\mathrm{X}_{5}\right)$, scan rate $\left(\mathrm{X}_{7}\right)$, ligand concentration $\left(\mathrm{X}_{8}\right), \mathrm{pH}\left(\mathrm{X}_{9}\right)$ and amplitude pulse $\left(\mathrm{X}_{10}\right)$.

Table 2. Plackett-Burman Experimental Design derived from factor in Table 1

\begin{tabular}{ccccccccccccc}
\hline Run & \multicolumn{10}{c}{ Factor/Parameter } & Response \\
\cline { 2 - 9 } & $\mathrm{X}_{1}$ & $\mathrm{X}_{2}$ & $\mathrm{X}_{3}$ & $\mathrm{X}_{4}$ & $\mathrm{X}_{5}$ & $\mathrm{X}_{6}$ & $\mathrm{X}_{7}$ & $\mathrm{X}_{8}$ & $\mathrm{X}_{9}$ & $\mathrm{X}$ & $\mathrm{X}_{1}$ & \\
\hline 1 & 1 & 1 & -1 & 1 & 1 & 1 & -1 & -1 & -1 & 1 & -1 & $4.33 \mathrm{E}-06$ \\
2 & -1 & 1 & 1 & -1 & 1 & 1 & 1 & -1 & -1 & -1 & 1 & $4.34 \mathrm{E}-05$ \\
3 & 1 & -1 & 1 & 1 & -1 & 1 & 1 & 1 & -1 & -1 & -1 & 0 \\
4 & -1 & 1 & -1 & 1 & 1 & -1 & 1 & 1 & 1 & -1 & -1 & $1.05 \mathrm{E}-05$ \\
5 & -1 & -1 & 1 & -1 & 1 & 1 & -1 & 1 & 1 & 1 & -1 & $2.19 \mathrm{E}-05$ \\
6 & -1 & -1 & -1 & 1 & -1 & 1 & 1 & -1 & 1 & 1 & 1 & $1.38 \mathrm{E}-05$ \\
7 & 1 & -1 & -1 & -1 & 1 & -1 & 1 & 1 & -1 & 1 & 1 & $3.27 \mathrm{E}-05$ \\
8 & 1 & 1 & -1 & -1 & -1 & 1 & -1 & 1 & 1 & -1 & 1 & 0 \\
9 & 1 & 1 & 1 & -1 & -1 & -1 & 1 & -1 & 1 & 1 & -1 & $9.85 \mathrm{E}-06$ \\
10 & -1 & 1 & 1 & 1 & -1 & -1 & -1 & 1 & -1 & 1 & 1 & $3.02 \mathrm{E}-06$ \\
11 & 1 & -1 & 1 & 1 & 1 & -1 & -1 & -1 & 1 & -1 & 1 & $4.01 \mathrm{E}-06$ \\
12 & -1 & -1 & -1 & -1 & -1 & -1 & -1 & -1 & -1 & -1 & -1 & $2.78 \mathrm{E}-05$ \\
\hline
\end{tabular}

The ANOVA of surface response quadratic model was chosen to analyze the selected factors. The ANOVA table is presented in Table 3 .

The selected factors were optimized based on Box-Behnken design through three levels: low level (-1), intermediate level (0) and high level (1). The Box-Behnken design of selected factors is shown in Table 4.

From Box-Behnken design, the optimum condition of amplitude pulse, scanning rate, supporting electrolyte solution, concentration of DTPA ligand and $\mathrm{pH}$ are $0.5489 \mathrm{~V}$; $0.05 \mathrm{Vs}^{-1}, \mathrm{NH}_{4} \mathrm{Cl} 0.1 \mathrm{M} ; 267.67 \mathrm{mgL}^{-1}$ and 5.15, respectively. The p-value was 0.4697 ( $\mathrm{p}>0.05$ ) and $\mathrm{R}$ square 0.6659 ,

\begin{tabular}{|c|c|c|c|c|c|}
\hline \multicolumn{6}{|c|}{ Analysis of variance table [Partial sum of squares - Type III] } \\
\hline & Sum of & & Mean & $\mathrm{F}$ & p-value \\
\hline Source & Squares & df & Square & Value & Prob $>$ F \\
\hline Model & 2.01E-09 & 20 & $1.00 \mathrm{E}-10$ & 1.99 & 0.0657 \\
\hline $\begin{array}{l}\text { A-Pulse } \\
\text { Amplitudo }\end{array}$ & $2.93 \mathrm{E}-10$ & 1 & $2.93 \mathrm{E}-10$ & 5.83 & 0.0255 \\
\hline $\mathrm{B}-\mathrm{pH}$ & 8.97E-12 & 1 & 8.97E-12 & 0.18 & 0.6774 \\
\hline C-Scan Rate & $3.90 \mathrm{E}-11$ & 1 & $3.90 \mathrm{E}-11$ & 0.77 & 0.3893 \\
\hline D-Ligand & 3.39E-11 & 1 & & & .4214 \\
\hline E-Electrolite & $9.87 \mathrm{E}-11$ & 1 & & & .176 \\
\hline
\end{tabular}
respectively.

Table 3. ANOVA for Response Surface Quadratic model 


\begin{tabular}{|c|c|c|c|c|c|}
\hline $\mathrm{AB}$ & $5.81 \mathrm{E}-11$ & 1 & $5.81 \mathrm{E}-11$ & 1.15 & 0.2953 \\
\hline $\mathrm{AC}$ & $1.73 \mathrm{E}-11$ & 1 & $1.73 \mathrm{E}-11$ & 0.34 & 0.5644 \\
\hline $\mathrm{AD}$ & $2.18 \mathrm{E}-11$ & 1 & $2.18 \mathrm{E}-11$ & 0.43 & 0.5183 \\
\hline $\mathrm{AE}$ & $1.46 \mathrm{E}-10$ & 1 & $1.46 \mathrm{E}-10$ & 2.9 & 0.1042 \\
\hline $\mathrm{BC}$ & $3.12 \mathrm{E}-11$ & 1 & $3.12 \mathrm{E}-11$ & 0.62 & 0.4401 \\
\hline $\mathrm{BD}$ & $4.11 \mathrm{E}-10$ & 1 & $4.11 \mathrm{E}-10$ & 8.17 & 0.0097 \\
\hline $\mathrm{BE}$ & $8.88 \mathrm{E}-12$ & 1 & $8.88 \mathrm{E}-12$ & 0.18 & 0.6789 \\
\hline $\mathrm{CD}$ & $6.46 \mathrm{E}-11$ & 1 & $6.46 \mathrm{E}-11$ & 1.28 & 0.2704 \\
\hline $\mathrm{CE}$ & $1.17 \mathrm{E}-10$ & 1 & $1.17 \mathrm{E}-10$ & 2.32 & 0.1434 \\
\hline $\mathrm{DE}$ & $2.78 \mathrm{E}-10$ & 1 & $2.78 \mathrm{E}-10$ & 5.53 & 0.029 \\
\hline A2 & $1.74 \mathrm{E}-10$ & 1 & $1.74 \mathrm{E}-10$ & 3.47 & 0.0774 \\
\hline B2 & $5.48 \mathrm{E}-11$ & 1 & $5.48 \mathrm{E}-11$ & 1.09 & 0.3091 \\
\hline $\mathrm{C} 2$ & $1.39 \mathrm{E}-10$ & 1 & $1.39 \mathrm{E}-10$ & 2.77 & 0.1118 \\
\hline D2 & $2.31 \mathrm{E}-10$ & 1 & $2.31 \mathrm{E}-10$ & 4.58 & 0.0448 \\
\hline E2 & $3.49 \mathrm{E}-11$ & 1 & $3.49 \mathrm{E}-11$ & 0.69 & 0.4147 \\
\hline Residual & 1.01E-09 & 20 & $5.03 \mathrm{E}-11$ & & \\
\hline Cor Total & 3.01E-09 & 40 & & & \\
\hline Std. Dev. & 7.09E-06 & & $\begin{array}{l}\text { R-Square } \\
\text { d }\end{array}$ & 0.6659 & \\
\hline Mean & $1.19 \mathrm{E}-05$ & & $\begin{array}{l}\text { Adj } \\
\text { R-Square } \\
\text { d }\end{array}$ & 0.3318 & \\
\hline C.V. \% & 59.79 & & $\begin{array}{l}\text { Pred } \\
\text { R-Square } \\
\text { d }\end{array}$ & N/A & \\
\hline PRESS & N/A & & $\begin{array}{l}\text { Adeq } \\
\text { Precision }\end{array}$ & 4.779 & \\
\hline
\end{tabular}

Table 4. The Box-Behnken design of selected factors

\begin{tabular}{lccc}
\hline \multicolumn{1}{c}{ Factor } & \multicolumn{3}{c}{ Level } \\
& -1 & 0 & +1 \\
\hline $\mathrm{X}_{1}$ Amplitudes & $0.05 \mathrm{~V}$ & $0.075 \mathrm{~V}$ & $0.1 \mathrm{~V}$ \\
pulse & & & 7 \\
$\mathrm{X}_{2} \mathrm{pH}$ & 5 & 6 & $0.05 \mathrm{~V} \mathrm{~s}^{-1}$ \\
$\mathrm{X}_{3}$ Scan rate & $0.01 \mathrm{~V} \mathrm{~s}^{-1}$ & $0.03 \mathrm{~V} \mathrm{~s}^{-1}$ & $392.41 \mathrm{mgL}^{-1}$ \\
$\mathrm{X}_{4}$ Ligand \\
$\quad$ concentration \\
$\mathrm{X}_{5}$ Supporting \\
$\quad$ Electrolyte \\
$\quad$ Solution
\end{tabular}

\section{B. Differential pulse voltammetry detection of Gd-DTPA under the optimal conditions}

Under the optimized conditions, graphite pencil was applied for determination Gd-DTPA by differential pulse voltammetry. Peak Currents for different concentration of Gd-DTPA were illustrated in Fig. 1.

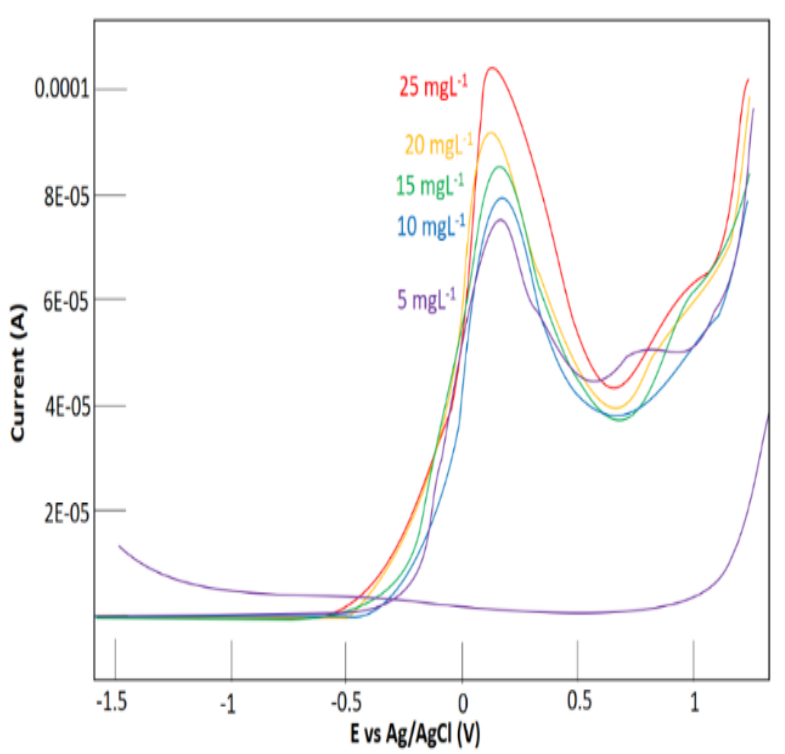

Fig. 1. Voltamogram of Gd-DTPA with variation concentration using differential pulse voltammetry (deposition time $=60 \mathrm{~s}$, scan rate $=0.05 \mathrm{Vs}^{-1}$, amplitude pulse $=0.5489 \mathrm{~V}$, electrolyte solution ammonium chloride $0.1 \mathrm{M}$, ligand concentration $=267.67 \mathrm{mgL}^{-1}$ and $\mathrm{pH}=5.15$ ).

The given deposition potential was adjusted to the Gd-DTPA concentration in the voltammetric cell based on Nernst equation. As shown in Fig. 1, the Gd-DTPA complex formation was detected by a single peak at the concentration of $20 \mathrm{mgL}^{-1}$ which shows the reduction current peak was at $0.113 \mathrm{~V}$. The higher current was increased with increases of concentration in the voltammetric cells. Probably due to the increased number of the Gd-DTPA complex species deposited on working electrode.

\section{Differential pulse voltammetry detection of Tb-DTPA under the optimal conditions}

Under the optimized conditions, the graphite pencil was applied for determination Tb-DTPA by differential pulse voltammetry. Peak Currents for different concentration of Tb-DTPA were illustrated in Fig. 2.

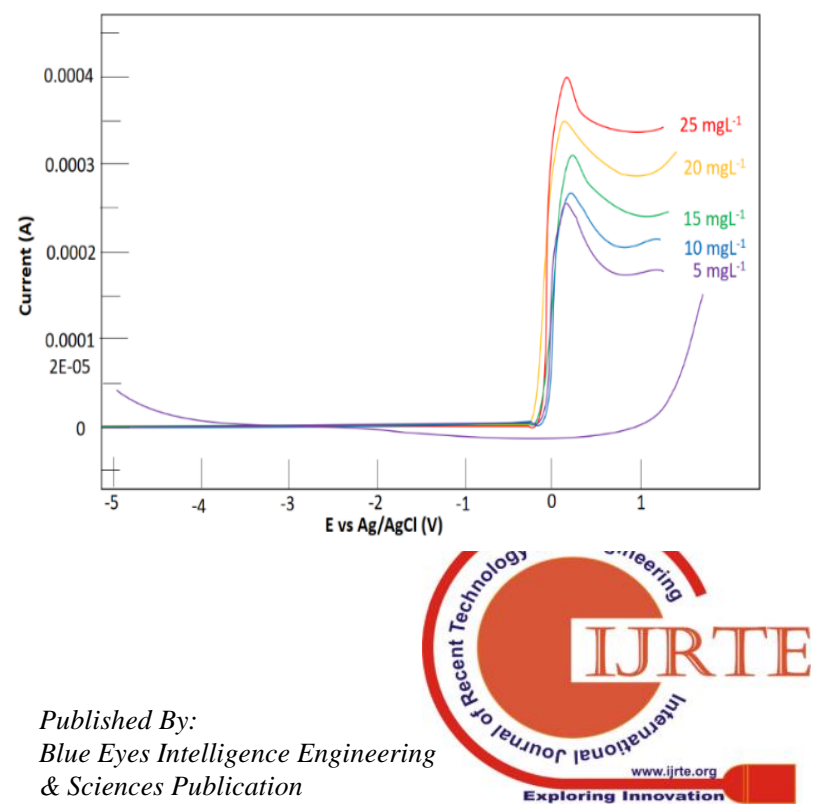


Fig. 2. Voltamogram of Tb-DTPA with variation concentration using differential pulse voltammetry (deposition time $=60 \mathrm{~s}$, scan rate $=0.05 \mathrm{Vs}^{-1}$, amplitude pulse $=0.5489 \mathrm{~V}$, electrolyte solution ammonium chloride $0.1 \mathrm{M}$, ligand concentration $=267.67 \mathrm{mgL}^{-1}$ and $\mathrm{pH}=5.15$ ).

As shown in Fig. 2, the reduction current of the Tb-DTPA complex was at a potential of $0.107 \mathrm{~V}$. The current height was increased with increases of concentration in the voltammetric cell. Probably due to the increased number of Tb-DTPA complex species which deposited on the working electrode when the Tb-DTPA concentration was increased. Therefore, the peak current in the voltammogram was increased.

\section{Calibration curve of Gd-DTPA and Tb-DTPA}

The result of calibration curve of GD-DTPA ad Tb-DTPA is shown in Fig. 3. The calibration curves and correlation coefficients that we obtained were: $Y=2 \times 10^{-5} X+0.0003$ and $\mathrm{R}^{2}=0.9814$ for Gd-DTPA and $Y=8 \times 10^{-6} X+0.0002$ and $\mathrm{R}^{2}=0.9749$ for Tb-DTPA. The obtained correlation coefficient $\left(R^{2}\right)$ which is close to 1 , indicated that the correlation of concentration and current response was strongly related. We obtained the precision of $99.7 \%$ and accuracy of $97.4 \%$ for detection of Gd-DTPA; while for precision and accuracy of Tb-DTPA were $99.5 \%$ and $91.4 \%$, respectively. Moreover, the detection limit and the quantization limit for Gd-DTPA were $27.109 \mathrm{mgL}^{-1}$ and $92.33 \mathrm{mgL}^{-1}$ and for Tb-DTPA were $27.69 \mathrm{mgL}^{-1}$ and 92.34 $\mathrm{mgL}^{-1}$, respectively.

\section{E. Differential pulse voltammetry detection of Tb-DTPA and Gd-DTPA in medium rare earth mixture under the optimal conditions}

We were prepared two mixtures based on ratio mole of metal: ligand $=1: 2$. The mixture 1 was prepared by the condition followed: $\mathrm{Gd}$ and $\mathrm{Tb}$ concentration of $25 \mathrm{mgL}^{-1}$, each, and the concentration of DTPA ligands was 403.868 $\mathrm{mgL}^{-1}$. The mixture 2 was prepared similar to the composition in monazite: the concentration of Gd was $25.3378 \mathrm{mgL}^{-1}$ and $\mathrm{Tb}$ was $16.3851 \mathrm{mgL}^{-1}$. The concentration of ligand which used for mixture 2 was $360.025 \mathrm{mgL}^{-1}$.

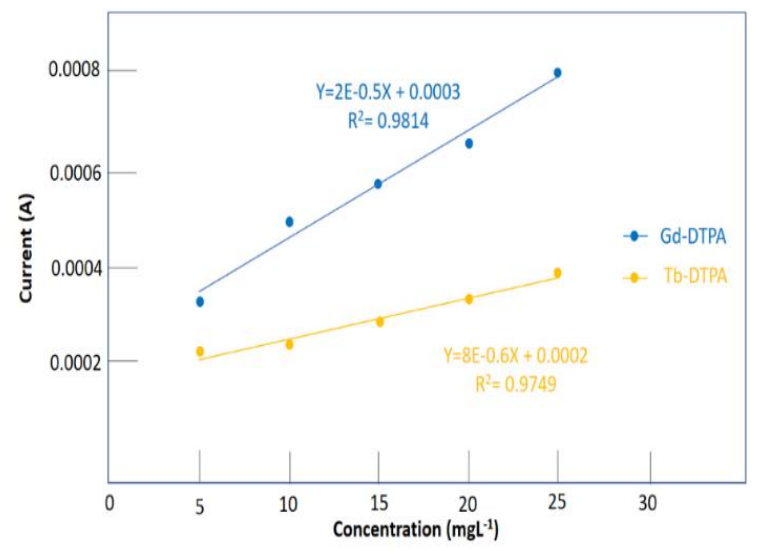

Fig. 3. Calibration curve of Gd-DTPA and Tb-DTPA with variation concentration using differential pulse voltammetry (deposition time $=60 \mathrm{~s}$, scan rate $=0.05 \mathrm{Vs}^{-1}$, amplitude pulse
$=0.5489 \mathrm{~V}$, electrolyte solution ammonium chloride $0.1 \mathrm{M}$, ligand concentration $=267.67 \mathrm{mgL}^{-1}$ and $\mathrm{pH}=5.15$ ).

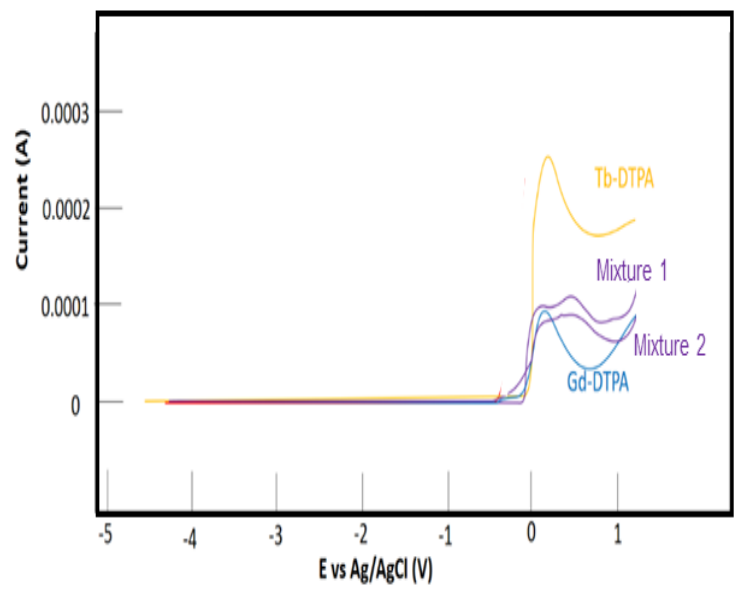

Fig. 4. Voltammogram of Gd-DTPA, Tb-DTPA mixture 1 and mixture 2 using differential pulse voltammetry (deposition time $=60 \mathrm{~s}$, scan rate $=0.05 \mathrm{Vs}-1$, amplitude pulse $=0.5489 \mathrm{~V}$, electrolyte solution ammonium chloride 0.1 $\mathrm{M}$, ligand concentration $=267.67 \mathrm{mgL}-1$ and $\mathrm{pH}=5.15$ ).

As shown Fig. 4, the broadened peak was observed by the addition of DTPA ligands. The close potential reduction value of Gd-DTPA and Tb-DTPA were causing peak currents to overlap. The peak height of mixture was lower than of Gd-DTPA and Tb-DTPA peak, probably due to competition between two metals to form complexes which resulting the lower peaks. Mixture 1 was produced a higher peak than mixture 2 because of a higher concentration of rare earth than mixture 2.

\section{CONCLUSION}

1. The results of this study indicate that the influence factors for determination of $\mathrm{Gd}$ and $\mathrm{Tb}$ as complexes with DTPA by differential pulse voltammetry based on Plackett-Burman experimental design were amplitude pulse, scan rate, electrolyte solution, ligand concentration and $\mathrm{pH}$.

2. The optimum conditions based on Box-Behnken experimental design were amplitude pulse of $0.5489 \mathrm{~V}$, scan rate of $0.05 \mathrm{Vs}^{-1}$, electrolyte solution ammonium chloride $0.1 \mathrm{M}$, DTPA ligand concentrations of 267.67 $\mathrm{mgL}^{-1}$ and $\mathrm{pH}$ of 5.15 .

3. Under the optimum experimental condition, the precision and accuracy were found as $99.7 \%$ and $97.4 \%$ for Gd-DTPA; and $99.5 \%$ and $91.4 \%$ for Tb-DTPA. The detection limit and quantization limit values for Gd-DTPA were $27.11 \mathrm{mgL}^{-1}$ and $92.33 \mathrm{mgL}^{-1}$, respectively; and Tb-DTPA were $27.69 \mathrm{mgL}^{-1}$ and 92.34 $\mathrm{mgL}^{-1}$, respectively. We believed this result is beneficial to join the race of green analysis by reducing the solvent and time consumption. 


\section{ACKNOWLEDGMENT}

The Author would like to acknowledge the financial support from Academic Leadership Grant Program, Universitas Padjadjaran, and the Directorate of Research and Community Service through Superior Research of Higher Education (DRPM-PUPT), Universitas for providing the research fund under contract number 1129/UN6.D/LT/2018 and Ranty Tania Jaelani who contributed to this research.

\section{REFERENCES}

1. P. Brouwer. Theory of XRF. Third Edition. Amelo, Netherlands: PANalytical BV, 2010.

2. T. Suzuki, K. Itoh, A. Ikeda, M. Aida, M. Ozawa and Y. Fujii. "Separation of rare earth elements by tertiary pyridine type resin." Journal of alloys and compounds, vol. 408, pp. 1013-1016, 2006.

3. P. Wannachod, S. Chaturabul, U. Pancharoena, A. W. Lothongkum and W. Patthaveekongka. "The effective recovery of praseodymium from mixed rare earths via a hollow fiber supported liquid membrane and its mass transfer related." Journal of Alloys and Compounds, vol. 509 no. 2, pp. 354-361, 2011.

4. M. M. Yusoff, N. R. N. Mostapa, M. S. Sarkar, T. K. Biswas, M. L. Rahman, S. E. Arshad, M. S. Sarjadi and A. D. Kulkarni. "Synthesis of ion imprinted polymers for selective recognition and separation of rare earth metals." Journal of Rare Earths, vol. 35, no. 2, pp. 177-186, 2017.

5. J. Wang. Analytical Electrochemistry, New York: Wiley-VCH, 2000.

6. S. T. Wyantuti, Y. W. Roekmiati. C. Hartati, C. Panatarani. "Fabrication of Gold Nanoparticles-Modified Glassy Carbon Electrode and Its Application For Voltammetric Detection Of Cr(III)." International Journal of Scientific \& Technology Research. vol. 4, no. 1, pp. 135-139, 2015.

7. Suyanta, Sunarto. L. P. Sari. N. I. Wardani. I. M. Isa. "Differential Adsorptive Stripping Voltammetric Determination of Ultra Trace Lanthanum(III) based on Carbon Paste Electrode Modified with 3-Methyl-2-hydrazinobenzothiazole." International Journal Electrochemical Science. vol. 9, pp. 7763-7772, 2014.

8. M. R. Pourjavid, P. Norouzi, M. R. Ganjali, A. Nemati, H. Ali Zamani and M. Javaheri. "Separation and Determination of Medium Lanthanides: A New Experiment with Use of Ion-Exchange Separation and Fast Fourier Transform Continuous Cyclic Voltammetry," International Journal of Electrochemical Science, vol. 4, pp. 1650-1671, 2009.

9. G. Derringer and R. Suich. "A strategy of robust parameter design for multiple responses," J. Qual. Technol. Vol. 12, pp. 214-219, 1980.

10. P. D. B. Harrington, N. E. Vieira, J. Espinoza, J. K. Nien, R. Romero and A. L. Yergey. "Analysis of variance-principal component analysis: A soft tool for proteomic discovery." Analytica chimica acta, vol. 544, no. 1, pp.118-127, 2005.

11. L. Pinto and S. G. Lemos. "Multivariate optimization of the voltammetric determination of $\mathrm{Cd}, \mathrm{Cu}, \mathrm{Pb}$ and $\mathrm{Zn}$ at bismuth film. Application to analysis of biodiesel. " Microchemical Journal, vol. 110, pp. 417-424, 2013.

12. J. Sarembaud, R. Pinto, D. N. Rutledge and M. Feinberg. "Application of the ANOVA-PCA method to stability studies of reference materials." Analytica chimica acta, vol. 603, no. 2, pp. 147-154, 2007.

13. K. Stemmler, G. Glod and U. Von Gunten. "Oxidation of metal-diethylenetriamine-pentaacetate (DTPA)-complexes during drinking water ozonation." Water research, vol. 35, no. 8, pp. 1877-1886, 2001 